OPEN ACCESS

Edited by:

Julio Aguirre,

University of Granada, Spain

Reviewed by:

Alan T. Critchley,

Cape Breton University, Canada

Megan Jane Huggett,

The University of Newcastle, Australia

*Correspondence:

Caroline L. Magil

cmagill02@qub.ac.uk

Specialty section:

This article was submitted to

Marine Ecosystem Ecology,

a section of the journal

Frontiers in Marine Science

Received: 23 November 2018

Accepted: 16 May 2019

Published: 06 June 2019

Citation:

Magill CL, Maggs CA

Johnson MP and O'Connor N (2019)

Sustainable Harvesting of the

Ecosystem Engineer Corallina

officinalis for Biomaterials.

Front. Mar. Sci. 6:285.

doi: 10.3389/fmars.2019.00285

\section{Sustainable Harvesting of the Ecosystem Engineer Corallina officinalis for Biomaterials}

\author{
Caroline L. Magill1*, Christine A. Maggs ${ }^{1,2}$, Mark P. Johnson ${ }^{1,3}$ and Nessa O’Connor ${ }^{1,4}$ \\ 1 School of Biological Sciences, Queen's University Belfast, Belfast, United Kingdom, ${ }^{2}$ Joint Nature Conservation \\ Committee, Monkstone House, Peterborough, United Kingdom, ${ }^{3}$ Ryan Institute and School of Natural Sciences, National \\ University of Ireland Galway, Galway, Ireland, ${ }^{4}$ Department of Zoology, Trinity College Dublin, Dublin, Ireland
}

Macroalgae are of increasing interest for high-value biotechnological applications, but some seaweeds, such as coralline red algae, cannot be grown in cultivation costeffectively. Wild harvesting of seaweeds, particularly of those that are ecosystem engineers, must be demonstrably sustainable: here we address the topic of resource sustainability in the context of harvesting Corallina officinalis in Ireland for bioceramics. C. officinalis provides habitat for a diverse macrofaunal community and the effects of harvesting $C$. officinalis on the associated fauna must be included in any assessment of harvesting sustainability. Corallina intertidal turfs subject to experimental harvesting were confirmed, using DNA barcoding with cox1, to comprise only C. officinalis and not the pseudocryptic species $C$. caespitosa, despite the wide range of morphologies, and they had high genetic diversity. Harvesting of $C$. officinalis was carried out at experimental sites by two techniques (hand cutting and pulling) to test the recovery of the primary resource and the associated macroinvertebrate assemblage. Harvesting the alga by both methods encouraged regrowth: cut and pulled plots had a much higher growth rate than unharvested turfs, regaining their original length within 4-6 months of harvesting, suggesting that turfs of this species may grow to a predetermined length. The structure, richness and evenness of the invertebrate assemblage were not significantly affected by harvesting $C$. officinalis by cutting or pulling, though some organisms within the community showed a response to harvesting. The pattern of recovery of the sediment, an important component of the $C$. officinalis habitat, was consistent with the shorter (harvested) turf trapping more sediment than longer natural turfs. As many of the organisms associated with the habitat use the sediment for food or building materials, this may have ameliorated the effects of harvesting on the community. A period of a year between harvests is recommended to allow the $C$. officinalis biomass to return to baseline levels and unharvested fallow areas should be included in a harvesting plan to allow macroinvertebrates to re-colonize the harvested turf.

Keywords: harvest, Corallinaceae, Ireland, macrofauna, sustainability 


\section{INTRODUCTION}

Algae are increasingly important as a potentially sustainable resource for biotechnological applications (Kim and Chojnacka, 2015; Rocha et al., 2018). Whilst microalgae are suitable for culture in bioreactors and some macroalgae, or seaweeds, are grown on frames and ropes in the open water (FAO, 2003-2015; Chung et al., 2017), other seaweeds are more efficiently harvested from the wild (McLaughlin et al., 2006; Mac Monagail et al., 2017). Wild algae can be commercially harvested either by hand or mechanically. Laminaria spp. (kelp) and other large subtidal canopy-forming algae can be harvested from boats equipped with cutting and raking tools (e.g., the Brittany "scoubidou") (Mesnildrey et al., 2012). Intertidal species with long thalli which float on the surface, such as Ascophyllum nodosum, can likewise be harvested mechanically at high tide by shallow-draft paddlewheel or water jet-driven cutters (Meland and Rebours, 2012). However, species with short or delicate thalli are not suitable for mechanical harvesting and must be harvested by hand. Manual (artisanal) harvesting of wild seaweeds has a long history in coastal communities, where they have been collected for food, medicine and as a soil improver (Reed, 1907; Morrissey et al., 2001; Mac Monagail et al., 2017; Yang et al., 2017). Manual harvesting is informed by traditional practices and hand harvesting of seaweeds is largely regarded as sustainable (McLaughlin et al., 2006; O'Toole and Hynes, 2014). However, even with hand harvesting there is a risk of over-exploitation. Unregulated wild harvest can lead to depletion of a species in an area, increasing market value and intensifying harvest efforts on the remaining resources (e.g., Chondracanthus chamissoi in Peru: Rebours et al., 2014).

Consequently, before harvesting begins on a commercial scale, sustainability of the resource under probable harvesting regimes must be assessed. An important element of sustainability is genetic diversity, but there are few studies of the genetic effects of harvesting seaweeds. Guillemin et al. (2014) attribute remarkably low diversity in Chilean populations of Gracilaria chilensis to a recent genetic bottleneck due to over-exploitation of natural stocks, which has been exacerbated by using genetically depressed populations as stock for aquaculture. In Brittany, France, populations of the economically important kelp Laminaria digitata exhibit greater genetic diversity within the Iroise Sea Marine Protected Area than outside it, and act as a source for other regions (Couceiro et al., 2013).

Whilst many commercially valuable algae are collected for their polysaccharides and cellular components (El Gamal, 2011; Kim and Chojnacka, 2015; Mac Monagail et al., 2017), coralline algae contain very little organic material in comparison with more fleshy species, and have been collected traditionally for their calcified skeleton (Wilson et al., 2004). Large quantities of free-living, non-geniculate coralline algae can occur in specific areas as maerl or rhodolith beds, which have traditionally been heavily exploited along the NE Atlantic coastline for lowvalue applications such as soil conditioning (Blunden et al., 1975). Maerl is also used in higher-value products such as food supplements for humans and domesticated animals (Nielsen et al., 2011; Ryan et al., 2011). However, the growth rate of the most abundant maerl species in Europe, Phymatolithon calcareum, is low (less than $2 \mathrm{~mm}$ per annum), which precludes sustainable harvesting (Blake and Maggs, 2003). In comparison with maerl, geniculate coralline species have a rapid growth rate and could potentially be considered renewable, whereas maerl is essentially a finite resource. Two species of the geniculate (jointed) coralline genus Corallina are currently recognized in the British Isles: Corallina officinalis and the semicryptic species C. caespitosa (Walker et al., 2009; Williamson et al., 2015). Genetic diversity of Corallina species is high on European coasts (France and Spain) (Pardo et al., 2015), and samples from southern England included several haplotypes (Walker et al., 2009).

Corallina officinalis occurs on rocky shores around most of the coast of Britain and Ireland, in easily accessible pools and crevices from the sublittoral fringe to the mid-shore (Irvine and Chamberlain, 1994). This widespread distribution could make it a better prospect for coastal communities to exploit on a part-time basis than the low-value fleshy species used for agriculture and food additives. The high-value applications for calcified algae (medical and cosmetic products) could mean a large return from a small amount of biomass collected. For example, C. officinalis has been identified as a feedstock for bone substitute materials (Kasperk et al., 1988; Turhani et al., 2005; Clarke et al., 2011) and a novel, low temperature process for the production of high quality material from C. officinalis was patented at Queen's University Belfast (Walker et al., 2007; Walsh et al., 2008, 2010, 2011). C. officinalis therefore offers a potentially sustainable alternative to the coral-derived bone substitutes that had been used clinically for dental and orthopedic applications, which makes it an attractive prospect for harvesting. Although Corallina spp. have traditionally been collected in small quantities in Britain, Ireland and elsewhere in Europe, there is no research underpinning best practice for harvesting (McLaughlin et al., 2006).

Like other geniculate species with similar morphology, C. officinalis is known to be a habitat-forming species or ecosystem engineer, which creates a reasonably stable and complex refuge from environmental stressors (Dommasnes, 1968; Bussell, 2003) and predation (Coull and Wells, 1983; Hayakawa et al., 2013), influencing the community structure of the shores on which it occurs (Kelaher, 2002; Nelson, 2009). The dense networks of semi-rigid thalli trap debris, which can be exploited as a food source (Hicks, 1986). C. officinalis also supports a community of macro-epiphytes (Munda, 1977; Stewart, 1982; Akioka et al., 1999; Berthelsen and Taylor, 2014) and micro-epiphytes (Perkins et al., 2016) which can be exploited as food. Animals that live amongst Corallina use the turf in various ways and exploit different aspects of the habitat. Harvesting the alga will change the habitat structure by affecting the amount of surface area available for settlement, refuge, grazing, and sediment capture - how long these effects persist could be important for resilience of invertebrate assemblages. Important biogenic habitats created by ecosystem engineers have been degraded by exploitation using unsustainable harvesting practices, aimed at the organisms themselves or associated species, e.g., Ostrea 
edulis (Airoldi and Beck, 2007), Modiolus modiolus (Strain et al., 2012) and maerl (Hall-Spencer and Moore, 2000; Hall-Spencer, 2005), and there is increasing awareness that they should be protected from disturbance and overexploitation (Cole et al., 2016). C. officinalis is not protected under any conservation legislation and it has not been harvested extensively to date. Therefore, a rare opportunity exists to assess the effects of harvest on the organisms associated with this ecosystem engineer in advance of its possible exploitation.

This study aimed to advance knowledge on harvesting of C. officinalis and to determine the feasibility of sustainable harvesting from the Irish coastline, including a preliminary determination of genetic diversity at the proposed harvest site using the DNA barcode marker cox1, which is also suitable for molecular identification. Firstly we assessed the regeneration of the alga after differing hand-harvesting methods. In a subsequent experiment, the a priori hypothesis that harvesting the $C$. officinalis turf would not change the diversity or structure of the associated invertebrate assemblage was tested. The community of animals living in coralline turf is known to recover rapidly after trampling (Brown and Taylor, 1999; Huff, 2011), therefore it was predicted that harvesting the alga would not have a lasting effect on the invertebrate assemblage. The effect of harvesting on important physical constituents of the habitat i.e., the coralline alga itself and the associated sediment were also tested, and time to recovery was estimated.

\section{MATERIALS AND METHODS}

\section{Field Study Sites}

Two readily accessible shores with sufficient coralline algal turf cover for experimental manipulation were selected on the north and east coast of Ireland in 2006 as part of the EU project HIPPOCRATES. Sites were chosen to represent exposure to different water bodies: Glashagh Bay, Fanad Head, Co., Donegal, Ireland is on the Northeast Atlantic coast and Killough Bay, Co., Down, Northern Ireland is situated in a bay opening into the Irish Sea (Figure 1). Glashagh Bay faces north-west with some shelter from the open Atlantic Ocean provided by offshore rocks and the shallow seabed which is $<10 \mathrm{~m}$ at $1 \mathrm{~km}$ from the shore. It is remote from tourist beaches and the algal turf is therefore at minimal risk of trampling or other anthropogenic damage. Killough Bay faces east into the Irish Sea with some shelter from a point on the north-eastern side of the bay, but it is exposed to waves from the south east. The tidal range for both shores is approximately $5 \mathrm{~m}$. At both sites Corallina $\mathrm{sp}(\mathrm{p})$ is dominant in the majority of pools from low water of spring tides (LWST) to mean tide level (MTL), forming a turf of varying height. The rock pools support an array of macroalgal species, including filamentous (e.g., Caradoriella (formerly Polysiphonia) elongata and Ceramium virgatum) and coarsely branched (e.g., Osmundea hybrida and Gelidium spp.) red algae; ephemeral (e.g., Ulva compressa) and perennial (e.g., Codium tomentosum) green algae and brown canopy algae (e.g., Fucus vesiculosus and Halidrys siliquosa). Encrusting coralline algae covered most of the remaining substratum.

\section{Effect of Harvesting on Growth of Corallina officinalis Turf}

Following visual surveys of both sites, pools with extensive coverage of Corallina sp(p.) were chosen for the first study at Fanad Head (two replicate pools) and Killough (one pool). The pools at Killough $\left(54^{\circ} 14^{\prime} 43.04^{\prime \prime} \mathrm{N} 5^{\circ} 38^{\prime} 15.01^{\prime \prime} \mathrm{W}\right)$ and Fanad A $\left(55^{\circ} 15^{\prime} 47.21^{\prime \prime} \mathrm{N} 7^{\circ} 40^{\prime} 45.10^{\prime \prime} \mathrm{W}\right)$ were of a similar depth, with rocky substrata throughout. Corallina grew in dense foliose clumps throughout the pools, with the only other major algal coverage being Fucus spp. Pool B at Fanad $\left(55^{\circ} 15^{\prime} 49.19^{\prime \prime} \mathrm{N}\right.$ $7^{\circ} 40^{\prime} 37.10^{\prime \prime} \mathrm{W}$ ) was at higher elevation on the shore with a deep area in the center having substantial sedimentation. The Corallina in this pool grew in short scrubby clumps mainly around the edges of the pool. Replicate plots $(n=3)$ of $25 \mathrm{~cm} \times 25 \mathrm{~cm}$ to be prepared for three experimental harvesting treatments and comparable unharvested controls $(n=3)$ were randomly distributed within each of the pools.

To mimic methods used for harvesting other algae, and suitable for large-scale harvesting of Corallina, experimental treatments included both cutting and pulling the C. officinalis thalli. The treatments were applied as follows: (1) coralline algal turf was cut to $\sim 30 \mathrm{~mm}$ length with scissors; (2) coralline algal turf was cut to $\sim 10 \mathrm{~mm}$ length with scissors; and (3) all coralline algal turf was completely pulled by hand from the basal crustose holdfast, the "pull" treatment, in three replicate quadrats in each pool. With all harvesting methods care was taken to leave the crustose holdfast intact, because in comparison to regeneration of uprights from an existing crustose base, formation of new thalli from spores is slow. The same number of control quadrats of coralline algal turf were left untouched in each pool to estimate ambient algal growth for comparison.

To estimate growth rate and determine when the alga returned to pre-harvested length, thalli were measured in all quadrats: at both pools at Fanad in late February and Killough in early March 2006 (before harvest: month 0) then in August and November 2006 at Fanad (after 6 and 10 months) and in July and November 2006 at Killough (after 4 and 10 months). Ten C. officinalis thalli were measured to the nearest $\mathrm{mm}$ from base to tip (thallus length $=$ turf height) within each replicate quadrat on each visit; mean thallus length in each quadrat was the basic unit for analysis (see section "Data Analyses"). Increase in thallus length in each quadrat was calculated by subtracting thallus length at one timepoint from the next. Thallus length increase was then converted to growth rate in $\mathrm{mm} \mathrm{mo}^{-1}$ by dividing the length increase by the number of months between measurements.

\section{Molecular Identification and Genetic Diversity of Corallina officinalis in Donegal}

To ensure the target species was harvested, and to obtain a preliminary assessment of genetic diversity, samples representing the full morphological range of Corallina from different habitats (differing in shore height and pool depth) were collected from Glashagh Bay, Fanad Head in January 2009. Thalli from five different individuals, representing the range of morphological variation (Supplementary Material 1), were photographed, 

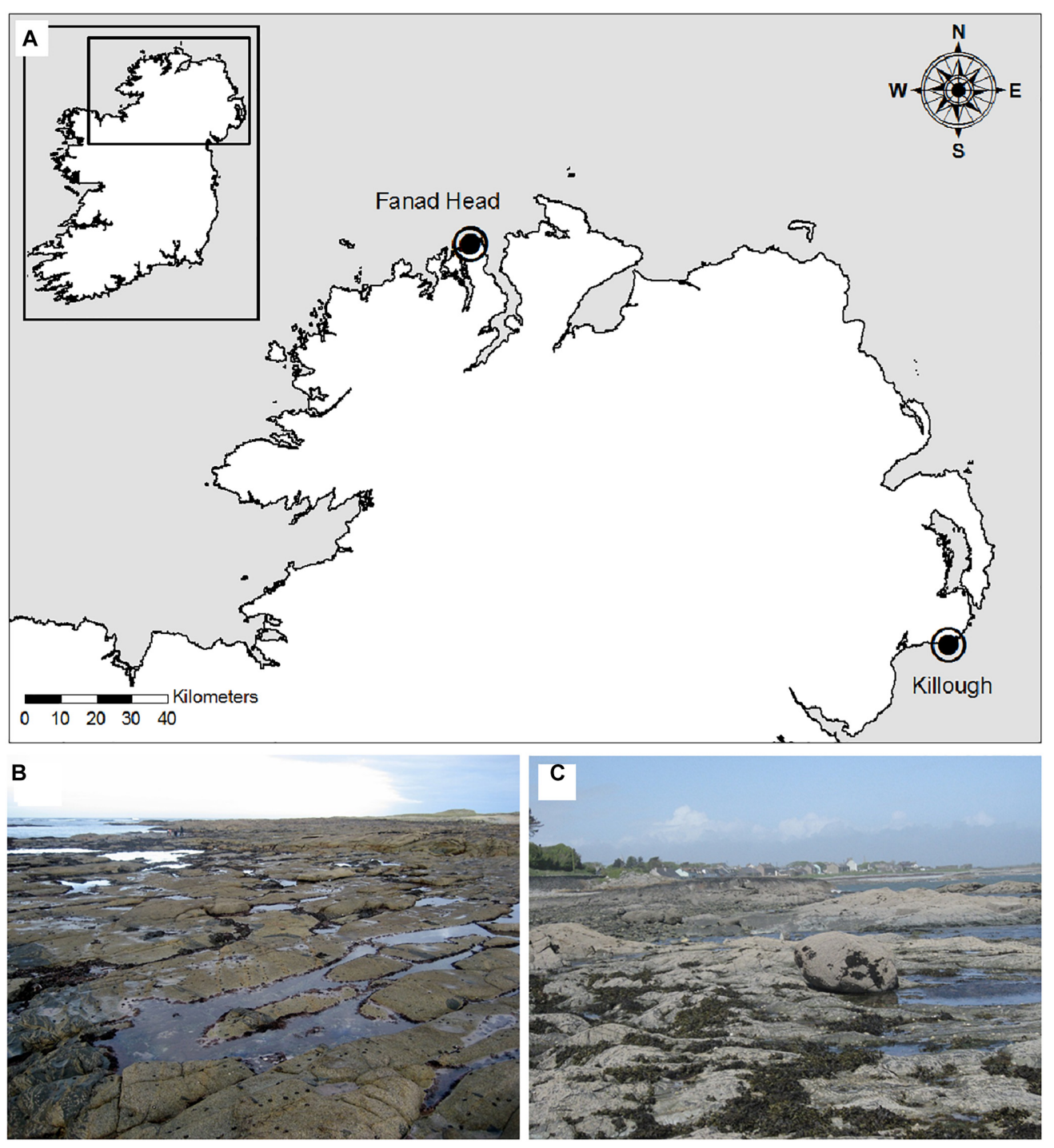

FIGURE 1 | (A) Experimental harvesting sites at Glashagh Bay, Fanad Head, Co., Donegal and Killough, Co., Down and shores where Corallina officinalis was harvested in pools at (B) Glashagh Bay and (C) Killough.

rinsed, picked clean by hand of epiphytes and epifauna, blotted dry and preserved in silica gel prior to DNA extraction. Voucher specimens for the Corallina sequences were pressed and deposited in the Natural History Museum, London.

After grinding $\sim 20 \mathrm{mg}$ of the dried sample with liquid nitrogen in an Eppendorf tube using an autoclaved minipestle, DNA was extracted with the Qiagen DNeasy Plant Mini Kit (Qiagen Ltd., W. Sussex, United Kingdom). The variable cox 1 region was amplified using the primers GazF1 $5^{\prime}$ TCAACAAATCATAAAGATATTGG $3^{\prime}$ and GazR1 5' ACTTCTGGATGTCCAAAAAAYCA 3' (Saunders, 2005). PCR conditions (Perkin Elmer DNA Thermal Cycler 480; Perkin Elmer Biosystems) were $5 \mathrm{~min}$ at $94^{\circ} \mathrm{C}, 35$ cycles of $1 \mathrm{~min}$ at $94^{\circ} \mathrm{C}, 1.5 \mathrm{~min}$ at $51^{\circ} \mathrm{C}$ (annealing), $2 \mathrm{~min}$ at $72^{\circ} \mathrm{C}$, and a final extension of $5 \mathrm{~min}$ at $72^{\circ} \mathrm{C}$. Purification and sequencing of the PCR products were outsourced to Macrogen
(Seoul, Korea). New sequences were uploaded to GenBank (Supplementary Material 2).

Sequences were edited in Codon Code Aligner version 6.02 (Codon Code Corporation), checking variable nucleotides carefully, and complementary strands were assembled in SeaView version 4 (Gouy et al., 2010). An alignment was constructed with other sequences of members of the tribe Corallineae, mostly Corallina spp., selected from GenBank using BLAST searches and relevant publications (Brodie et al., 2013; Pardo et al., 2015). Sequences that were identical to those selected from the same geographical region were ignored. A compressed alignment with all variable sites (Supplementary Material 2) was used to assign sequences to haplotypes. The amino acid translation was examined in SeaView. Phylogenetic network estimation using statistical parsimony was carried out with TCS 1.21 (Clement et al., 2000). Using Corallina vancouveriensis as 
outgroup resulted in too many ambiguities so the network was made with no outgroup.

\section{Effects of Harvesting Corallina officinalis on the Diversity of the Invertebrate Community}

Glashagh Bay, Fanad Head (Figure 1) was chosen for the second study in 2010 as it is representative of sites in the area but has a more extensive coverage of $C$. officinalis than others, making it a potential commercial harvesting site and allowing for a larger scale study. To separate the effects of harvesting on the variability in communities from those caused by shore height (Kelaher et al., 2001; Bussell et al., 2007), a large pool (approximately 0.5-1 m above Chart Datum) that spanned c. $30 \mathrm{~m}$ horizontally along the shore but was only c. $5 \mathrm{~m}$ max. width, with an estimated $\sim 80 \%$ Corallina cover, was chosen as an experimental area (Figure 2a). The pool consisted of varying microhabitats, from very shallow sills to deep crevices, and supported a diverse algal community.

A destructive sampling program was designed to avoid repeated measures analysis and maintain independent data among sampling occasions. Five replicates of each experimental treatment, for each sampling month [cut harvesting $(n=30)$, pull harvesting $(n=30)$ and no harvesting $(n=35)]$, were randomly assigned a $25 \mathrm{~cm} \times 25 \mathrm{~cm}$ numbered grid square within a $1 \mathrm{~m} \times 1 \mathrm{~m}$ alphabetical quadrat area (see Supplementary Materials 3, 4 for sample list and grids, respectively). These alphabetical areas were then transferred onto the pool in June 2010 by haphazardly placing a guide quadrat of the same size in 12 (A-L) different parts of the pool with continuous Corallina cover and marking their location (Figure 2b). Harvesting treatment areas were demarcated when applying the treatments by aligning a quartered $50 \times 50 \mathrm{~cm}$ quadrat with the outer edges of the $1 \times 1 \mathrm{~m}$ guide quadrat (Figure $2 \mathrm{c}$ ). Alternate $25 \mathrm{~cm} \times 25 \mathrm{~cm}$ grid squares within the smaller quadrat were designated as "fallow" areas to minimize autocorrelation between treatment squares (Figure 2 inset).

Pre-ordained destructive baseline samples $(10 \mathrm{~cm} \times 10 \mathrm{~cm}$; $n=5$ ) were taken in June 2010 before applying the allocated harvesting treatments to all plots. Harvesting treatments were then applied as in the previous harvesting trials, with the modification that only one cut treatment was applied $(\sim 2 \mathrm{~cm})$ (e.g., Figure 2d). The unharvested plots underwent the procedure of placing the quadrat, without harvesting. Depth measurements, to be used as co-variates in the analysis, were taken at low tide when all channels draining the pool were empty or still. Nine measurements (Figure 2f, gray dots) were taken in each $25 \mathrm{~cm} \times 25 \mathrm{~cm}$ grid square with a ruler from the bottom of the pool to the water surface and the mean of these measurements represented the depth for that sample. The mean water depth of the sampled plots was $44 \mathrm{~mm}$ (range $0-187 \mathrm{~mm}$, Supplementary Material 5).

Destructive sampling of a $10 \mathrm{~cm} \times 10 \mathrm{~cm}$ portion in the center of the $25 \mathrm{~cm} \times 25 \mathrm{~cm}$ plot (to minimize "edge effects" i.e., spatial autocorrelation) of the cut, pulled and unharvested plots commenced 1 month after harvest in July 2010, and continued at months 4 (October 2010), 7 (January 2011), 10 (April 2011),
13 (July 2011), and 16 (October 2011) after harvest treatment (Figure 2e). On each sampling occasion, five of the pre-ordained, randomly assigned replicates of cut, pull, and unharvested treatments were collected (see Supplementary Material 3 for sampling schedule). The $10 \mathrm{~cm} \times 10 \mathrm{~cm}$ sample of coralline turf and associated fauna (Figures 2e,f) was enclosed in a plastic bag, by pushing the bag down over the sample, removed with a scraper and immediately transferred to a sorting tray. Any large, easily identifiable animals were photographed, logged and returned to the pool. The remaining material was transferred to a Ziploc bag and then preserved in labeled jars with $90 \%$ ethanol within $2 \mathrm{~h}$ of collection.

The samples composed of coralline turf, sediment, flora and fauna removed from the plots were processed by gently rinsing with running seawater through stacked Endicott sieves of $1 \mathrm{~mm}, 500$ and $63 \mu \mathrm{m}$ mesh. The $63-500 \mu \mathrm{m}$ and the $>1 \mathrm{~mm}$ fraction (Corallina and associated fauna) were included in the analyses. The sediment fraction for each plot was transferred to a separate foil tray and oven dried at $60^{\circ} \mathrm{C}$ in a Gallenkamp oven (Weiss-Gallenkamp, Loughborough, United Kingdom). Prior to weighing, the samples were allowed to cool to room temperature in a desiccator. Samples were then weighed to the nearest $0.1 \mathrm{~g}$ with an Ohaus Adventurer AR3130 (Ohaus, Nanikon, Switzerland). Once the associated flora and fauna had been removed, the denuded C. officinalis fraction was processed in the same way as the sediment.

The $>1 \mathrm{~mm}$ fraction of the sample contained coralline algae, epiphytic algae, terete species, epifauna, slow-moving associated fauna and large debris. After removing debris and other freeliving algae, the samples were processed under a dissecting microscope. Once the coralline alga had been picked clean, it was dried as detailed previously. Animals were identified using the literature and online material listed in Supplementary Material 6, and identification was corroborated by J. Nunn, National Museums Northern Ireland. Free-living annelid worms were not counted as they were most often fragmented and it was impossible to ascertain the number of animals accurately.

\section{Data Analyses}

\section{Effect of Harvesting on Growth of Corallina officinalis Turf}

The basic sampling unit for analysis was the mean thallus length in each quadrat, rather than the individual measurements, as the 10 measurements from each quadrat were considered spatial pseudoreplicates (Millar and Anderson, 2004). Growth rate was used as the response variable in the subsequent analysis rather than thallus length, as a priori comparison of thallus lengths at time 0 , before harvesting treatments were applied, revealed a significant difference in initial length between treatment plots $(p=<0.001)$. As sampling at the sites was unbalanced, pools were not nested within site and each pool was treated as a separate entity in the analyses.

To compare overall (10 months) growth rates, univariate ANOVA with Treatment (fixed, four levels) and Pool (random, three levels) as factors was used. Post hoc Tukey's HSD test was applied to resolve differences in significant terms. Data were checked for normality and homogeneity of variances with the 




FIGURE 2 | (a) Location of sampling areas in pool. (b) Markers drilled to allow exact placement of guide quadrat. (c) Example of a harvesting grid and quadrat placement. (d) Guide quadrat after applying harvesting treatments on June 2010 [two harvesting treatments applied (cut and pull), five future control samples left untouched (top two control plots marked on picture only) and one baseline control plot sampled]. (e) Detail of $10 \mathrm{~cm} \times 10 \mathrm{~cm}$ sampling quadrat in place. (f) Example of a plot after sampling (dots indicate approximately where depth measurements were taken in each $25 \mathrm{~cm} \times 25 \mathrm{~cm}$ quadrat).

Shapiro-Wilk and Cochran's $C$ test, respectively. These analyses were conducted in R version 3.1.2 (R Core Team, 2015).

To test for any effect of time of year on the algal growth after harvest, growth rates $\left(\mathrm{mm} \mathrm{mo}^{-1}\right)$ during the two intervals between measurements (spring/summer and autumn/winter) were compared with Permutational multivariate analysis of variance (PERMANOVA+ add-on in PRIMER version 6.1.13; PRIMER-E Ltd., Plymouth, United Kingdom). The univariate PERMANOVA was based on the same model structure as the ANOVA with the addition of Interval as a two level fixed factor.
The analysis was performed on a Euclidean distance dissimilarity matrix of untransformed growth rates in $\mathrm{mm} \mathrm{mo}^{-1}$. Control data were not considered in this analysis. In one case where a zero growth rate was recorded (possibly due to breakage of the thallus) the value was replaced with a dummy variable of 0.01 .

\section{Effects of Harvesting Corallina officinalis on the Diversity of the Invertebrate Community}

Species were grouped by the lowest taxonomic group practicable to test for difference in diversity and assemblage structure. In 


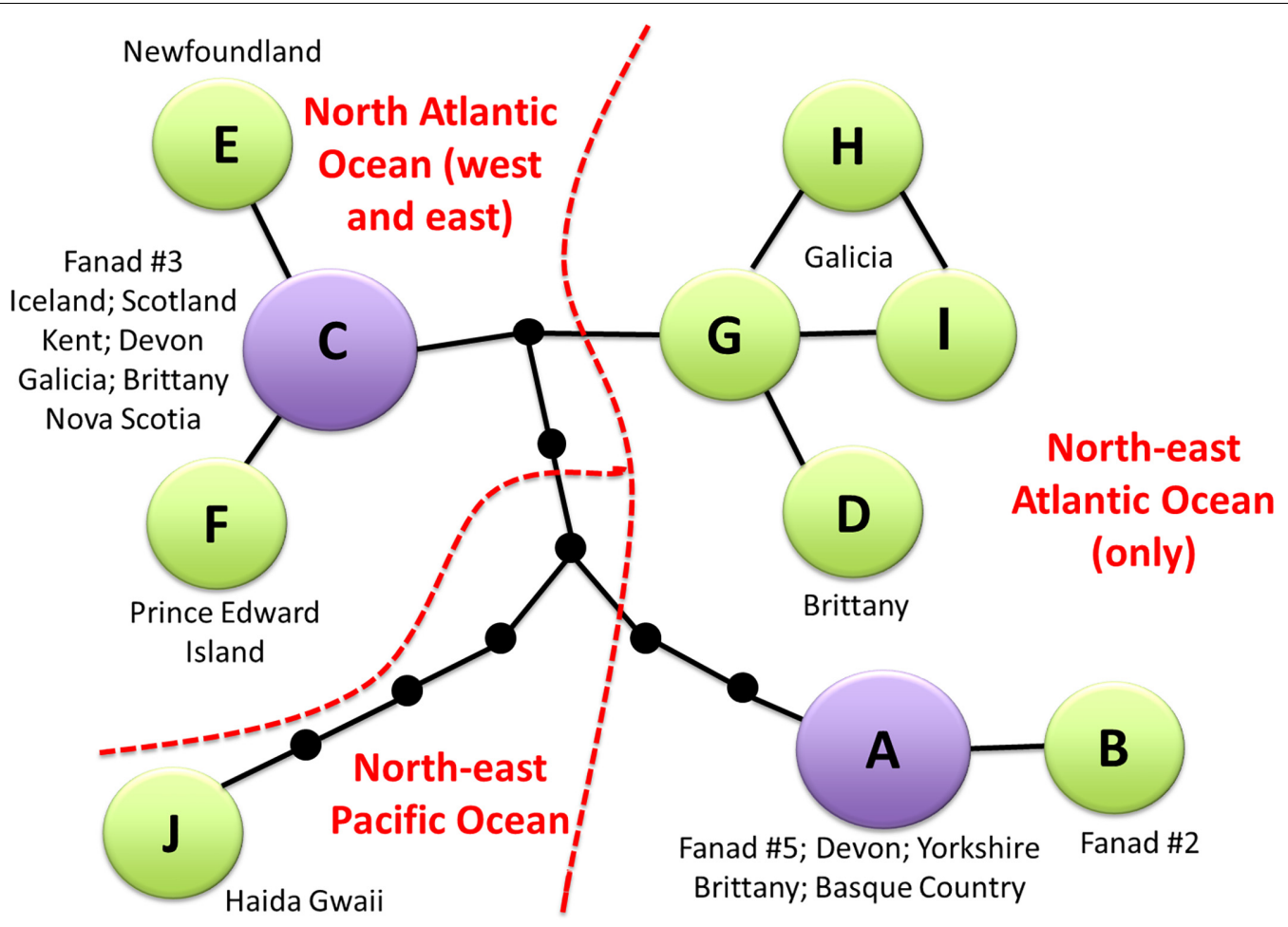

FIGURE 3 | Parsimony network for cox1 sequences of Corallina officinalis from Fanad sampling site and sequences from GenBank generated in TCS. The compressed alignment is shown in Supplementary Material 2. Relationships between haplotypes are depicted with black lines and small black dots indicate missing haplotypes. Haplotypes A and C (purple) are the two commonest and most widespread. An overview of the biogeographical distribution is presented in red.

most cases the taxonomic grouping was by order. In the case of several gastropod species, which have no formally assigned order (WoRMS Editorial Board, 2015), subclass was used as grouping level. Insect larvae, nematodes and ascidians were grouped by phylum (Nematoda only), and class. This method of grouping allowed all invertebrates collected, except for 98 "unidentified tubes," to be included in the analyses.

Analyses were carried out on the " $\mathrm{R}$ " statistical computing framework (version 3.1.2, $\mathrm{R}$ Core Team, 2015). The a priori hypothesis that harvesting $C$. officinalis would have no effect on the sampled invertebrate community was tested using the manyglm function within the $\mathrm{R}$ package "mvabund" (Wang et al., 2015). The "manyglm" function was used to fit univariate negative binomial generalized linear models to the abundance of each invertebrate taxon in the community and relate the abundance to a common set of explanatory variables, resulting in a multivariate analysis across taxa (Moorhouse et al., 2014). The "anova" function was then used to generate resampling-based hypothesis tests of the multivariate abundance response. The abundance of invertebrate grouping taxa in each sample was the response variable in the model (90 observations of 26 variables), with harvest treatment (fixed, three levels), and months since treatment (fixed, six levels) as categorical variables (factors). Depth was included in the model as a continuous predictor (covariate). Model assumptions were checked by plotting the residuals to check for normality, i.e., random distribution on the plot (Supplementary Material 7). Any correlation between taxa (which would be expected in a community) was accounted for in the resampling method (PIT-trap, Warton et al., 2015).

Taxon richness (number of species in a sample, $S$ ) and evenness (relative abundance of different species in a sample, Simpson's, $1-\lambda$ ) of the associated invertebrates were compared with two-way factorial ANOVAs, with harvest treatment (fixed, three levels), and months since treatment (fixed, six levels) as factors, for the taxonomic groups over the entire study, as a broad-scale measures of effect of harvesting on the invertebrate community.

The structural habitat components, Corallina dry biomass and sediment dry mass, were $\log x+1$ transformed to normalize the variables then compared by the same method as the richness and evenness to check if and when the C. officinalis itself and sediment load within it returned to pre-harvesting levels.

\section{RESULTS}

\section{Identification and Genetic Diversity of Corallina Samples}

Sequence quality of the cox 1 sequences from five Fanad samples was good except for sample 4 in which only the forward sequence was usable. The alignment was 663 bp in length. Analysis of the cox 1 sequences, in an alignment with multiple GenBank sequences of Corallina spp., indicated that the five Fanad samples were all conspecific. They were identifiable as C. officinalis 
because some sequences were identical to the $C$. officinalis epitype cox 1 GenBank accession no. FM180073 from Devon (Brodie et al., 2013), which is also identical to the mitochondrial genome $\operatorname{cox} 1$ sequence (Supplementary Material 2).

The compressed alignment for C. officinalis included 16 variable sites, which resulted in ten haplotypes (Supplementary Material 2). These separated into two major groups of haplotypes (A + B; C-I), with haplotype J clearly divergent from both groups. There was high genetic variation in the Fanad samples: the five sequences represented three different haplotypes, A, B, and C. Haplotype B, with $\mathrm{T}$ rather than $\mathrm{C}$ at position 618, was private to Fanad. Parsimony network analysis (Figure 3) showed clear phylogeographic structure. It confirmed that Haplotype J, from Haida Gwaii, BC, is the most distant from the other haplotypes, and it differs by four non-synonymous substitutions. Two well-separated Fanad haplotypes had broad geographical distributions: haplotype A was found widely in Europe from Ireland to the Basque Country; haplotype $\mathrm{C}$ occurred in the north-east Atlantic, Iceland, and the north-west Atlantic. Haplotypes from Brittany and Galicia form a closely related grouping, with four nonsynonymous substitutions in total between this group and the other haplotypes.

\section{Effect of Harvesting on Growth of Corallina officinalis Turf}

Although growth rates varied amongst the harvested samples, they grew significantly faster than the unharvested controls (Figure 4 and Table 1). The maximum mean growth rate found in this study was $9 \mathrm{~mm} \mathrm{mo}^{-1}$ for cut harvest $\left(3 \mathrm{~cm}\right.$ ) and $6.3 \mathrm{~mm} \mathrm{mo}^{-1}$ for pull harvest (Supplementary Material 8). These growth rates are substantially higher than any

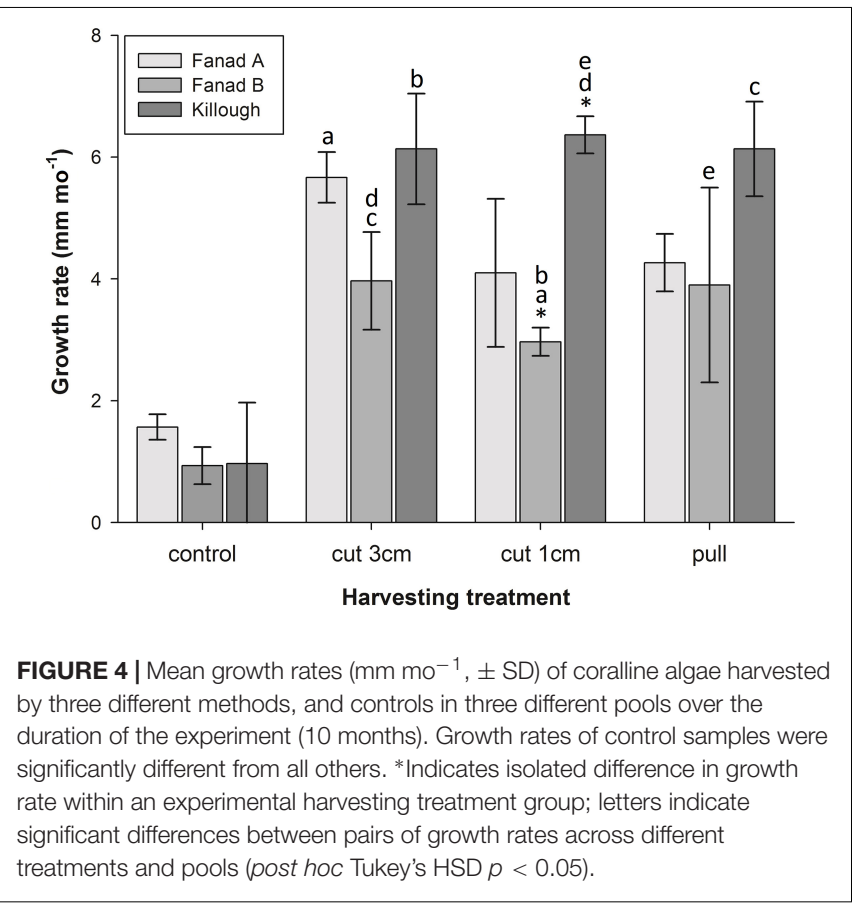

TABLE 1 | ANOVA results for the effects of harvesting treatment (cut $3 \mathrm{~cm}$, cut $1 \mathrm{~cm}$, and pull) and pool (Fanad A, Fanad B, and Killough) on growth rate of Corallina officinalis.

\begin{tabular}{lcccc}
\hline Source of variation & DF & MS & $\boldsymbol{F}$ & $\boldsymbol{P}$ \\
\hline Treatment & 3 & 31.36 & 48.29 & $<0.001$ \\
Pool & 2 & 11.51 & 17.72 & $<0.001$ \\
Treatment* pool & 6 & 2.02 & 3.12 & 0.020 \\
Residual & 24 & 0.65 & & \\
\hline
\end{tabular}

recorded for $C$. officinalis in the literature $\left(1.4-2.2 \mathrm{~mm} \mathrm{mo}^{-1}\right.$; Colthart and Johansen, 1973; Andrake and Johansen, 1980; Blake and Maggs, 2003). ANOVA indicated a significant difference in growth rates between different harvesting methods in the pools (Figure 4, letters on bars a-e). There was also a significant Treatment $\times$ Pool interaction, which was identified as an isolated difference between the growth rates of the $1 \mathrm{~cm}$ cut treatments at Fanad B and Killough. Within the other harvesting treatments there was no significant effect of pool, suggesting that at Fanad A and Killough, two geographically separated sites with similar pool topography and substratum type, the effect of harvesting on growth rate was similar.

The alga grew at different rates at different sites in the intervals (seasons) (PERMANOVA, Pool $\times$ Interval interaction $p=<0.006)$. Comparing the western and eastern sites with each other, Killough had the fastest growing $C$. officinalis in the early part of the year (interval 1, post hoc $p=<0.05$ ), whilst in the second interval there was no difference between the geographic areas. Within pools across all treatments, Killough and Fanad A grew at similar rates in both intervals, whilst Fanad B grew faster later in the year (post hoc $p=<0.05$; Figure 5). The maximum mean growth rates in each interval and in the experiment overall reflect these results (Supplementary Material 8). There was no difference between the thallus lengths of the three manipulated plots and the control plot at the sites within any measurement period (post hoc $p>0.05$ ).

\section{Effect of Harvesting on Invertebrate Assemblage Structure and Diversity}

The multivariate test for change in assemblage structure "manyglm" suggested there were effects of harvesting in some months (harvest $\times$ month interaction, Table 2, $p<0.05$ ). When the individual GLM results were examined (Table 2), these interaction effects were seen most strongly in six groups of animals (effect size in parentheses): Tanaidacea (Tanais dulongii) $(\mathrm{Dev}=30.309)$, Caenogastropoda (Bittium reticulatum) $(\mathrm{Dev}=26.575)$, Neogastropoda (Nucella lapillus) $(\mathrm{Dev}=25.688)$, Isopoda (Idotea spp.) (Dev = 24.77), Sabellidae (Spirorbis spp./Spirorbis corallinae) $(\mathrm{Dev}=23.435)$ and Nematoda $($ Dev $=22.742)$, although none of the effects were statistically significant $(p>0.05)$. The effects were variable and in some cases cutting and pulling the alga seemed to have a positive effect, as the abundances of animals collected from the cut and pulled plots were greater than those from the unharvested plots (see Figure 6). In the six taxonomic groups that differed most among experimental harvesting treatments, the effects 

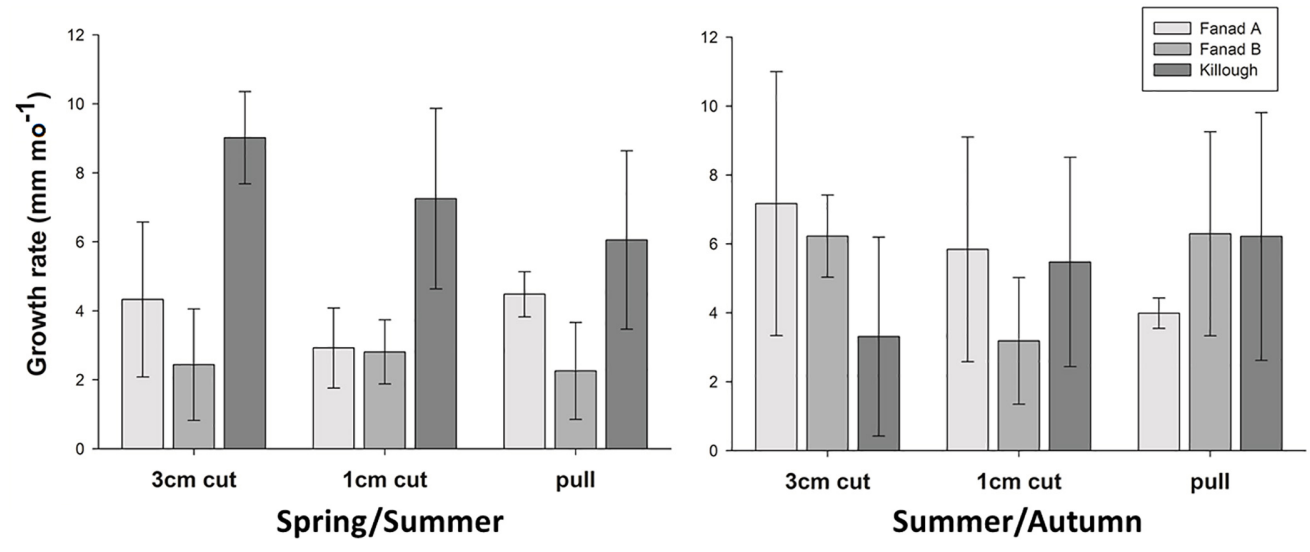

Harvesting treatment

FIGURE 5 | Mean growth rates ( $\mathrm{mm} \mathrm{mo}^{-1}, \pm \mathrm{SD}$ ) of coralline algae harvested by three different methods, in three different pools in interval $1 \mathrm{Spring} / \mathrm{Summer}$ (Killough: February-July; Fanad: March-August) and interval 2 Summer/Autumn (Killough: July-November; Fanad: August-November).

of harvesting $C$. officinalis turf were clearly seen in the first month after harvest, July 2010 (Figure 6, abundances on harvested alga compared with unharvested), though this only persisted beyond July in Isopoda. For the remainder of the experiment, harvesting the alga did not reduce the abundance of Tanaidacea and Nematoda in general (the pull and cut plots had the highest median abundance, respectively, in the majority of months). Caenogastropoda, Neogastropoda and Sabellidae showed variable abundances, with no discernible pattern. Depth of sample also played a role in the community changes (Table 2), though the only individual order on which this had a significant effect was Actinaria (anemones) (Dev $=19.228, p=0.002$ ).

Harvesting $C$. officinalis had no effect on invertebrate species richness $(S)$ or evenness $(1-\lambda)$, nor was there any harvest $\times$ month interaction (Supplementary Material 9). However, there was a significant effect of month on evenness $(p<0.001)$, suggesting strong seasonality in numbers for at least some of the groups of invertebrates.

\section{Effects of Experimental Harvesting Treatments on Structural Components of the Habitat}

Corallina officinalis and sediment mass were significantly affected by both harvesting and month (Supplementary Material 10 and Figure 7). Although the Corallina biomass in the cut and pull harvested plots differed from the June 2010 unharvested baseline in most months (Tukey's HSD, $p=<0.05$ ), the cut samples had recovered to pre-harvesting levels by July 2011 (after 1 year). Furthermore, biomass of the cut and pull harvested samples was not significantly different from the unharvested control plots in the same month at any time after July 2010 (the first month after harvest, at which time only the pull samples were different from the controls, Figure 7A; Tukey's HSD $p<0.001)$. This suggests that the unharvested biomass of Corallina decreased overall in the winter months and the baseline biomass recorded in June 2010 may have been a maximum.
The sediment mass in all plots in the winter months (October 2010; January 2011; and October 2011), and in the pull harvested samples in July 2010 and April 2011, was significantly different from the June 2010 baseline samples (Figure 7B; Tukey's HSD, $p<0.05)$. However, the only time in spring/summer that sediment mass differed between harvested and unharvested control samples within a month was in July 2010, a month after harvest, when the pull samples were significantly different from the controls (Tukey's HSD, $p=0.001$ ). This strong influence of time of year on sediment mass in relation to harvested algae was indicated by the significant harvest $\times$ month interaction (Supplementary Material 10).

\section{DISCUSSION}

This study was designed to test the potential for sustainable harvesting of Corallina officinalis on Irish shores using three manual methods. Harvesting C. officinalis stimulated growth, so it can be argued that it is in principle a renewable resource. Regeneration of thalli was equally rapid after harvesting by both cutting and pulling techniques, and increased significantly relative to unharvested areas. In fact, a cut plot at Killough showed the highest reported growth rate for this species. The meristematic tissues of erect axes of $C$. officinalis are apical, so when the thallus tips are removed lateral branches below the damage continue to grow, in a process resembling apical dominance in plants. Shearing by grazing organisms, which would have a similar effect to cutting in this study, has been found to stimulate growth of Corallina sp. in Japan (Akioka et al., 1999). In addition to lateral growth of axes after cut harvesting, the perennial crustose holdfast gives rise to new C. officinalis uprights at long as it remains intact. Littler and Kauker (1984) found that complete removal of articulated fronds by pulling stimulated generation of new uprights from the crustose base. This rapid regeneration after upright thalli have been destroyed or truncated is not surprising given that 
TABLE 2 | Results of multivariate test of change in assemblage structure followed by individual GLM results identifying taxa with significant or large effects.

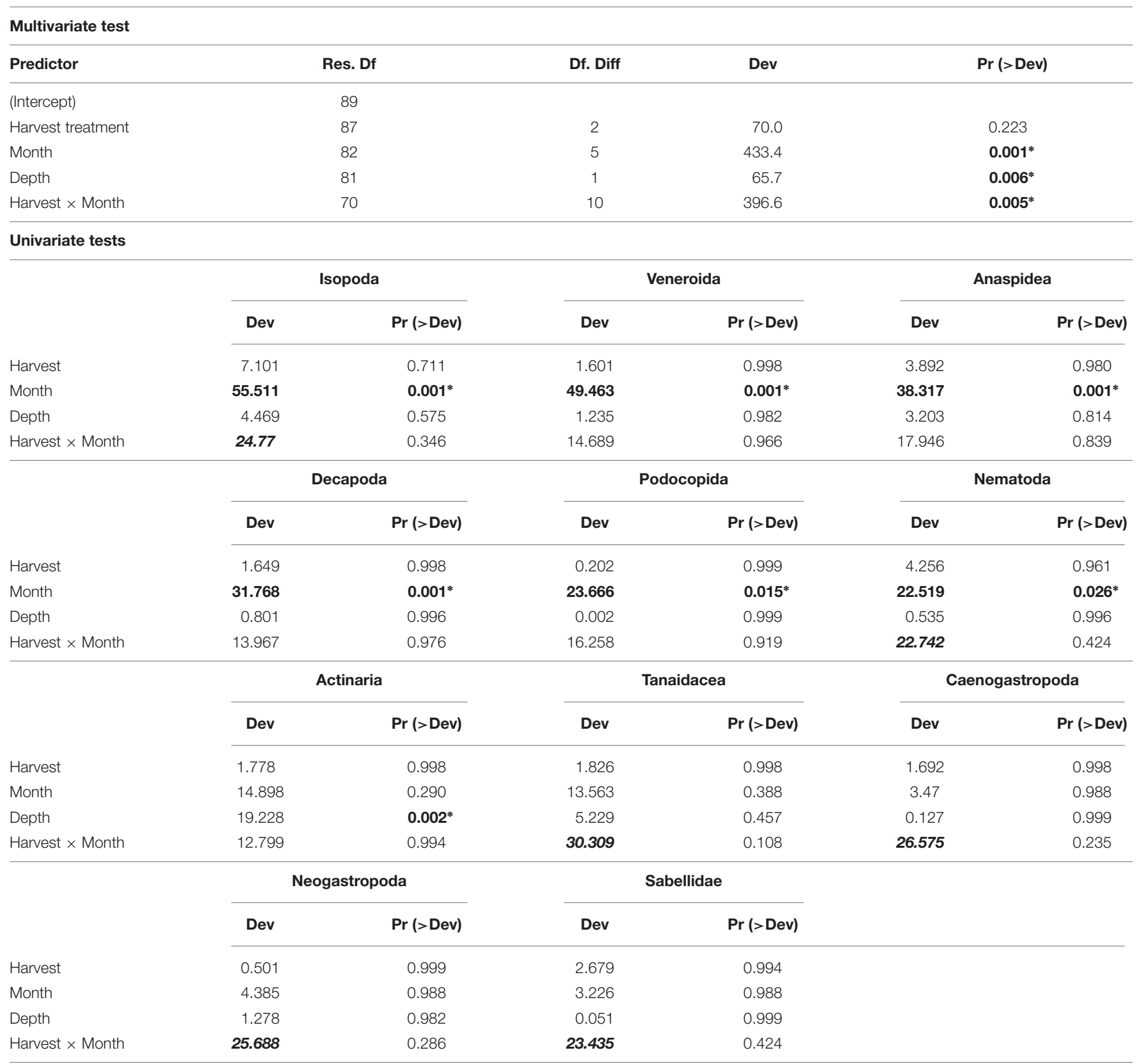

Taxa listed in order of effect size for a particular predictor. Large effects in bold, statistically significant effects in bold with*. In the case of the Harvest $\times$ Month interaction, non-significant but large effects are in bold italics.

C. officinalis has evolved in an environment where axes are frequently removed by wave action. It is likely that older heavily epiphytized axes add to the wave drag that results in their selective removal. This could be beneficial to the alga, like the loss of Chondrus crispus blades with heavy endophyte loads (Correa and McLachlan, 1992). This dual origin of new algal tissue (from axes and holdfast) means that harvesting C. officinalis either by cutting or pulling, methods which would be typical of commercial harvesting, ensures regeneration without the need for recruitment of new individuals. This is in marked contrast to Laminaria species, for example, which invariably die if the meristem between the stipe and blade is harvested (Birkett et al., 1998). Sustainable harvesting of these kelps requires expensive hand cutting above the meristem or depends on reliable recruitment of new individuals to bare patches created by mechanical harvesting (Smale et al., 2013).

After harvesting, C. officinalis had recovered its original thallus length through rapid regrowth by the date of the first measurement (4-6 months), but the speed of regeneration within this period is unknown. This means that it should be possible to harvest $C$. officinalis every $4-6$ months, although growth rates 

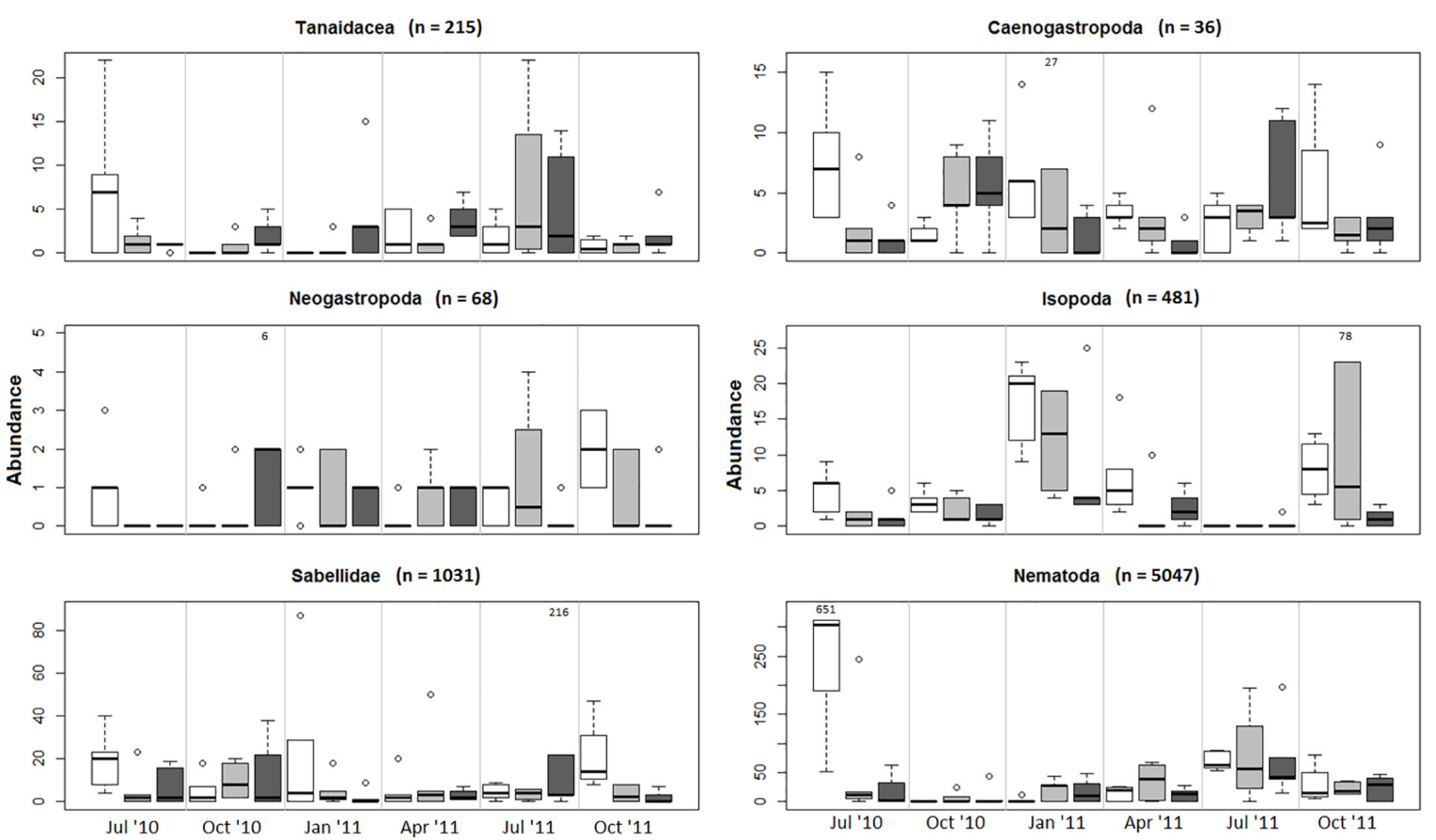

FIGURE 6 | Abundances plotted by harvesting method and month for the six groups with large Harvest $\times$ Month interaction effects (Dev $=>20$, Table 2). Effect of harvesting seen in all groups in the first month after harvest (July 2010). Extreme outliers are indicated on the plots. Note differing scales on y axes. Control, unshaded; Cut, light gray; Pull, dark gray. Line, median value; Box, 1st and 3rd quartiles; Whiskers, values falling within 1.5x range of quartiles; outliers are represented by open circles, extreme outlier values are marked.
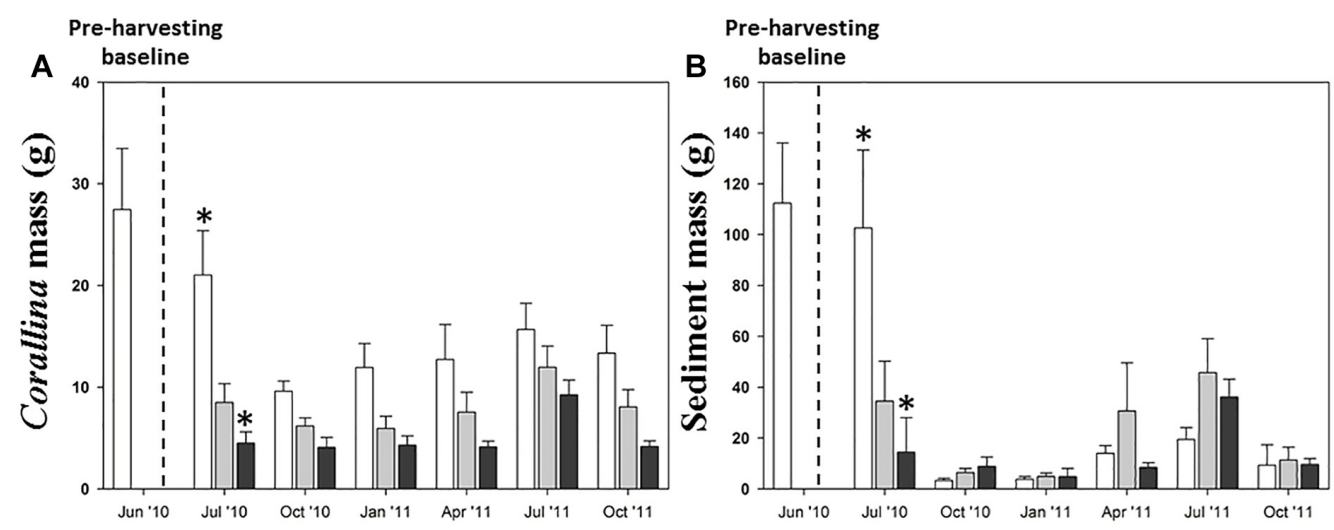

FIGURE 7 | (A) Corallina and (B) sediment mean mass ( \pm SE) in experimental harvesting treatments (unharvested control, unshaded; cut, light gray; pull, dark gray). *Significant differences between treatments (Tukey's HSD, $p<0.05$ ).

will vary with time of year and site. However, it should be noted that the experimentally harvested patches were small and uniform in size, and real harvesters would be more likely to intensively remove the alga from larger areas. The recovery of a system can depend on the size of the perturbation. In areas experimentally cleared of Ascophyllum nodosum on a sheltered shore in Maine, larger cleared areas $(>2 \mathrm{~m})$ were dominated over time (within 7 years) by either Fucus vesiculosus or Mytilus edulis, whereas smaller cleared areas returned to A. nodosum dominance within the same timeframe (Petraitis et al., 2009).
However, as discussed above, regeneration of C. officinalis from holdfasts and cut axes does not require recruitment of new individuals, so the process is very different from that taking place after total clearance of fucoids, and it is possible that results would scale up from small quadrats to large patches. Nevertheless, long-term monitoring of the recovery of the C. officinalis turf percentage cover would be advisable. Older, larger coralline thalli produce more reproductive structures (conceptacles) than young, smaller thalli (Martone, 2010), and the effect of harvesting on recruitment of new individuals should 
be a focus for further work on long-term harvesting effects on size of C. officinalis populations.

The complexity of the physical structure created by C. officinalis thalli has been shown to have a positive influence on the diversity and abundance of most fauna associated with the alga (Davenport et al., 1999; Kelaher, 2002). Although harvesting reduced the C. officinalis biomass, which remained lower than the controls throughout the study, the associated faunal community structure was not significantly affected by harvesting the alga. This suggests, in agreement with previous studies, and with the role of $C$. officinalis as an ecosystem engineer, that the complexity of the habitat, i.e., the amount of physical substratum provided by the algal fronds, was not the sole factor responsible for structuring the associated invertebrate community.

Recovery of the sediment, an important component of the C. officinalis habitat, revealed that harvested fronds may have trapped more sediment than unharvested thalli, due to the denser thallus matrix. As many of the organisms associated with the habitat use the sediment for food or building materials, this may have ameliorated the effects of harvesting on the community. C. officinalis grows from apices by elongation of meristematic cells (Matty and Johansen, 1981); if the main apices are removed by cutting, growth of branchlets continues. This can result in an increase in lower branching, as was found after shearing of thalli by grazers in Japan (Akioka et al., 1999). Likewise with the pull harvest, the short fronds initiated rapidly from the crustose holdfast (Littler and Kauker, 1984) may have trapped more sediment than long and foliose thalli. In accordance with observations by Bussell et al. (2007), shorter turf in shallower areas retains more sediment than the longer more mobile fronds in deeper areas. Reducing the length of fronds in deeper areas of the pool by harvesting could increase sediment accretion by reducing mobility of the thalli as well as increasing the density of branching. However, the nature of the sediment accreted can also change. After experimental harvesting of $A$. nodosum in Ireland, sediments were coarser, attributed to the change in hydrodynamic conditions with less dampening of turbulence by the long and buoyant fronds (Boaden and Dring, 1980).

Sediment provides construction material for tube-dwelling organisms such as tanaiids. When sediment was elevated in the harvested plots, in comparison with the unharvested, there was a marked increase in abundance of Tanais dulongii in comparison with the previous year. Female T. dulongii build their tubes from sediment at the base of $C$. officinalis fronds (Johnson and Attramadal, 1982) and the increase in $T$. dulongii on the harvested samples in the year after harvest may relate to the increased amount of sediment available in the plots, as suggested by Bueno et al. (2016) in Brazil. The amount of sediment in coralline algal turfs is positively correlated with the richness and abundance of gastropods (Kelaher et al., 2001; Kelaher and Castilla, 2005), and nematodes are generally found at higher densities in turf algae and sediment (Gibbons and Griffiths, 1986). Two groups of gastropods (Caenogastropoda and Neogastropoda) and nematodes had large effects sizes for the harvest $\times$ month interaction in this study. Caenogastropoda was composed of the grazing snail Bittium reticulatum, which is associated with sandy bottoms or sediment-rich compact algae (SánchezMoyano et al., 2000; Marriner et al., 2005), and Neogastropoda of small numbers of the predatory whelk Nucella lapillus, which probably use C. officinalis at pool edges as refuge from predatory decapods and desiccation at low tide (Burrows and Hughes, 1991). However, there was no clear pattern of change owing to harvesting in either group, with numbers in the unharvested and harvested plots fluctuating throughout the year. Nematodes mostly remain in the sediment (Armonies, 1988) where they feed by several different modes depending on the species: deposit feeding (including diatoms), predation, and scavenging (Jensen, 1987), and there was a striking similarity between the sediment and nematode abundance throughout the experiment, in terms both of seasonal fluctuation and harvesting treatment differences.

Evaluating the effects of harvesting on the community composition was a critical part of this research. Even immediately after harvesting, the invertebrate community associated with C. officinalis turfs was not significantly affected although there were some relatively large non-significant effects on some groups of invertebrates. This information coupled with the rapid regeneration of the resource itself strongly suggests that C. officinalis is a sustainable source of biogenic calcium carbonate. Previously, optimal harvesting intervals and methods have been determined for a range of species based only on regeneration time (Baardseth, 1970; Pringle and Sharp, 1980; Keser and Larson, 1984; Ang et al., 1996; Lazo and Chapman, 1997). There are very few examples of investigations of full community effects (e.g., A. nodosum in Ireland and New England), which are required for true sustainability studies. Boaden and Dring's (1980) study of communities when cutting A. nodosum to $18 \mathrm{~cm}$ had good taxonomic coverage (algae and invertebrates) but was limited to a single time period, 2.5 years after the cut. The significant differences they found in algae and some invertebrates were no longer evident 30 years after the harvest (Gregory, 2007). In Maine, United States, comparing the effects on the A. nodosum community of cutting at lengths of 18 and $36 \mathrm{~cm}$ showed that the community was resilient to a lower intensity disturbance $(36 \mathrm{~cm}$ cut), recovering within 2 years (Fegley, 2011). Stagnol et al. (2015) reported varying results for species diversity of the communities associated with various harvested seaweed species in Brittany, following the effects for a total of 12 months. Another aspect of sustainability of harvesting natural resources is the effect on genetic diversity of the target species (Guillemin et al., 2014). Here, our preliminary study showed a high genetic diversity in C. officinalis, comparable to that in Galicia (Pardo et al., 2015), suggesting a lack of isolation and greater resilience to impacts including anthropogenic disturbance.

Potential new high-value products, ranging from pigments to proteins and polysaccharides, are constantly being developed from species of red seaweeds (Thomas and Kim, 2013). For some of these newly valuable red algae, wild harvests could be a possible source of biomass for extraction of the desired products. Although wild harvests cannot produce a high biomass of seaweeds in Europe, it might be feasible to wild-harvest 
sufficient quantities of species that are sources of high-value biotechnological or pharmaceutical products. In order to ensure that commercial harvesting of a macroalgal resource is carried out in a sustainable manner, harvesting trials using different methods should be conducted to assess the effect of those methods on the target species (Vasquez, 1995; McLaughlin et al., 2006). However, C. officinalis is a biogenic-habitat-forming organism and ecosystem engineer (Crain and Bertness, 2006) and the communities associated with the Corallina turf cannot be omitted from an assessment of sustainability of harvest. Demonstrating the sustainability of harvesting C. officinalis in Ireland therefore required a broad approach to understanding the resource and its regeneration after harvesting, as well as the effects of harvesting on the associated invertebrate community.

\section{AUTHOR CONTRIBUTIONS}

CLM, CAM, NO'C, and MJ designed the study. CLM conducted the study. CLM and CAM wrote the manuscript.

\section{REFERENCES}

Airoldi, L., and Beck, M. W. (2007). Loss, status and trends for coastal marine habitats of Europe. Oceanogr. Mar. Biol. 45, 345-405. doi: 10.1201/ 9781420050943.ch7

Akioka, H., Baba, M., Masaki, T., and Johansen, H. W. (1999). Rocky shore turfs dominated by Corallina (Corallinales, Rhodophyta) in northern Japan. Phycol. Res. 47, 199-206. doi: 10.1046/j.1440-1835.1999.00164.x

Andrake, W., and Johansen, H. W. (1980). Alizarin red dye as a marker for measuring growth in Corallina officinalis L. (Corallinaceae, Rhodophyta). J. Phycol. 16, 620-622. doi: 10.1111/j.0022-3646.1980.00620.x

Ang, P. O., Sharp, G. J., and Semple, R. E. (1996). Comparison of the structure of populations of Ascophyllum nodosum (Fucales, Phaeophyta) at sites with different harvesting histories. Hydrobiologia 326, 179-184. doi: 10.1007/ bf00047804

Armonies, W. (1988). Active emergence of meiofauna from intertidal sediment. Mar. Ecol. Prog. Ser. 43, 151-159. doi: 10.3354/meps043151

Baardseth, E. (1970). Seasonal variation in Ascophyllum nodosum (L.) Le Jol. in the Trondheimsfjord with respect to the absolute live and dry weight and the relative contents of dry matter, ash and fruit bodies. Bot. Mar. 13, 13-22.

Berthelsen, A. K., and Taylor, R. B. (2014). Arthropod mesograzers reduce epiphytic overgrowth of subtidal coralline turf. Mar. Ecol. Prog. Ser. 515, 123-132. doi: 10.3354/meps11025

Birkett, D. A., Maggs, C. A., Dring, M. J., Boaden, P. J. S., and Seed, R. (1998). Infralittoral Reef Biotopes with Kelp Species. An Overview of Dynamic and Sensitivity Characteristics for Conservation Management of Marine SACs, Vol. VII. Oban: Scottish Association of Marine Science.

Blake, C., and Maggs, C. A. (2003). Comparative growth rates and internal banding periodicity of maerl species (Corallinales, Rhodophyta) from northern Europe. Phycologia 42, 606-612. doi: 10.2216/i0031-8884-42-6-606.1

Blunden, G., Binns, W. W., and Perks, F. (1975). Commercial collection and utilisation of maerl. Econ. Bot. 29, 141-145. doi: 10.1007/bf02863313

Boaden, P. J., and Dring, M. T. (1980). A quantitative evaluation of the effects of Ascophyllum harvesting on the littoral ecosystem. Helgol. Meeresuntersuchungen 33, 700-710. doi: 10.1007/bf02414790

Brodie, J., Walker, R. H., Williamson, C. J., and Irvine, L. M. (2013). Epitypification and redescription of Corallina officinalis L., the type of the genus, and $C$. elongata Ellis et Solander (Corallinales, Rhodophyta). Cryptogam. Algol. 34, 49-56. doi: 10.7872/crya.v34.iss1.2013.49

Brown, P. J., and Taylor, R. B. (1999). Effects of trampling by humans on animals inhabiting coralline algal turf in the rocky intertidal. J. Exp. Mar. Biol. Ecol. 235, 45-53. doi: 10.1016/s0022-0981(98)00186-5

\section{FUNDING}

This work was funded partly under the FP6-funded HIPPOCRATES project (NMP3-CT-2003-505758) and partly by the Department for Employment and Learning Northern Ireland under the Programme for Government initiative.

\section{ACKNOWLEDGMENTS}

We thank Dr. Charmaine Beer (DAERA), Prof. Fraser Buchanan (QUB), and Dr. Pamela Walsh (QUB) for their contributions to the fieldwork and work on bioceramics.

\section{SUPPLEMENTARY MATERIAL}

The Supplementary Material for this article can be found online at: https://www.frontiersin.org/articles/10.3389/fmars. 2019.00285/full\#supplementary-material

Bueno, M., Dena-Silva, S. A., Flores, A. A. V., and Leite, F. P. P. (2016). Effects of wave exposure on the abundance and composition of amphipod and tanaidacean assemblages inhabiting intertidal coralline algae. J. Mar. Biol. Assoc. U.K. 96, 761-767.

Burrows, M. T., and Hughes, R. N. (1991). Variation in foraging behaviour among individuals and populations of dogwhelks, Nucella lapillus: natural constraints on energy intake. J. Anim. Ecol. 60, 497-514.

Bussell, J. A. (2003). Biodiversity of the Invertebrate Community Associated with the Turf-forming Red Alga Corallina officinalis in Tide Pools. Doctoral dissertation. Bangor: University of Wales.

Bussell, J. A., Lucas, I. A., and Seed, R. (2007). Patterns in the invertebrate assemblage associated with Corallina officinalis in tide pools. J. Mar. Biol. Assoc. U.K. 87, 383-388. doi: 10.1017/s0025315407055385

Chung, I. K., Sondak, C. F. A., and Beardall, J. (2017). The future of seaweed aquaculture in a rapidly changing world. Eur. J. Phycol. 52, 495-505. doi: 10. 1080/09670262.2017.1359678

Clarke, S. A., Walsh, P., Maggs, C. A., and Buchanan, F. (2011). Designs from the deep: marine organisms for bone tissue engineering. Biotechnol. Adv. 29, 610-617. doi: 10.1016/j.biotechadv.2011.04.003

Clement, M., Posada, D., and Crandall, K. (2000). TCS: a computer program to estimate gene genealogies. Mol. Ecol. 9, 1657-1660.

Cole, V. J., Hutchings, P. A., and Ross, P. M. (2016). Predicting biodiversity changes due to loss of bioengineers from an intertidal landscape, a case study from Sydney Harbour. Aust. Zool. 39, 194-206. doi: 10.7882/AZ.2015.034

Colthart, B. J., and Johansen, H. W. (1973). Growth rates of Corallina officinalis (Rhodophyta) at different temperatures. Mar. Biol. 18, 46-49. doi: 10.1007/ bf00347919

Correa, J. A., and McLachlan, J. L. (1992). Endophytic algae of Chondrus crispus (Rhodophyta). IV. Effects on the host following infections by Acrochaete operculata and A. heteroclada (Chlorophyta). Mar. Ecol. Prog. Ser. 81, 73-87. doi: 10.3354/meps081073

Couceiro, L., Robuchon, M., Destombe, C., and Valero, M. (2013). Management and conservation of the kelp species Laminaria digitata: using genetic tools to explore the potential exporting role of the MPA "Parc naturel marin d'Iroise". Aqu. Living Resour. 26, 197-205. doi: 10.1051/alr/20 12027

Coull, B. C., and Wells, J. B. J. (1983). Refuges from fish predation: experiments with phytal meiofauna from the New Zealand rocky intertidal. Ecology 64, 1599-1609. doi: 10.2307/1937513

Crain, C. M., and Bertness, M. D. (2006). Ecosystem engineering across environmental gradients: implications for conservation and management. Bioscience 56, 211-218. doi: 10.1002/ece3.5040 
Davenport, J., Butler, A., and Cheshire, A. (1999). Epifaunal composition and fractal dimensions of marine plants in relation to emersion. J. Mar. Biol. Assoc. U.K. 79, 351-355. doi: 10.1017/s0025315498000393

Dommasnes, A. (1968). Variations in the meiofauna of Corallina officinalis L. with wave exposure. Sarsia 34, 117-124. doi: 10.1080/00364827.1968.1041 3376

El Gamal, A. A. (2011). "Biological importance of marine algae," in Handbook of Marine Macroalgae: Biotechnology and Applied Phycology, ed. S. K. Kim (Hoboken, NJ: John Wiley and Sons), 3-27.

FAO (2003-2015). Fisheries and Aquaculture topics. Ecosystems. Topics Fact Sheets. Rome: FAO Fisheries and Aquaculture Department.

Fegley, J. C. (2001). Ecological Implications of Rockweed, Ascophyllum nodosum (L.) Le Jolis, harvesting. Ph.D. Thesis. Orono, ME: University of Maine.

Gibbons, M. J., and Griffiths, C. L. (1986). A comparison of macrofaunal and meiofaunal distribution and standing stock across a rocky shore, with an estimate of their productivities. Mar. Biol. 93, 181-188. doi: 10.1007/bf0050 8255

Gouy, M., Guindon, S., and Gascuel, O. (2010). SeaView version 4: a multiplatform graphical user interface for sequence alignment and phylogenetic tree building. Mol. Biol. Evol. 27, 221-224. doi: 10.1093/molbev/msp259

Gregory, L. (2007). Assessments of Recovery 30 years After Algal (Ascophyllum nodosum) Harvesting at Rathcunningham Quay, Co. Down, Northern Ireland. Belfast: Queen's University Belfast.

Guillemin, M. L., Valero, M., Faugeron, S., Nelson, W., and Destombe, C. (2014). Tracing the trans-Pacific evolutionary history of a domesticated seaweed (Gracilaria chilensis) with archaeological and genetic data. PLoS One 9:e114039. doi: 10.1371/journal.pone.0114039

Hall-Spencer, J. M. (2005). Ban on maerl extraction. Mar. Pollut. Bull. 50, 121-124. Hall-Spencer, J. M., and Moore, P. G. (2000). Scallop dredging has profound, long-term impacts on maerl habitats. ICES J. Mar. Sci. 57, 1407-1415. doi: 10.1006/jmsc. 2000.0918

Hayakawa, J., Kawamura, T., Kurogi, H., and Watanabe, Y. (2013). Shelter effects of coralline algal turfs: protection for Turbo cornutus juveniles from predation by a predatory gastropod and wrasse. Fish. Sci. 79, 15-20. doi: 10.1007/s12562012-0569-2

Hicks, G. R. F. (1986). "Meiofauna associated with rocky shore algae," in The Ecology of Rocky Coasts, eds P. G. Moore and R. Seed (New York, NY: Columbia University Press), 36-56.

Huff, T. M. (2011). Effects of human trampling on macro-and meiofauna communities associated with intertidal algal turfs and implications for management of protected areas on rocky shores (Southern California). Mar. Ecol. 32, 335-345. doi: 10.1111/j.1439-0485.2011.00467.x

Irvine, L. M., and Chamberlain, Y. M. (eds) (1994). "Seaweeds of the British Isles Vol 1: Rhodophyta; Part 2B,” Corallinales, Hildenbrandiales (London: HMSO).

Jensen, P. (1987). Feeding ecology of free-living aquatic nematodes. Mar. Ecol. Prog. Ser. 35, 187-196. doi: 10.1186/s13071-017-2030-y

Johnson, S. B., and Attramadal, Y. G. (1982). Reproductive behaviour and larval development of Tanais cavolinii (Crustacea: Tanaidacea). Mar. Biol. 71, 11-16. doi: $10.1007 /$ bf00396987

Kasperk, C., Ewers, R., Simons, B., and Kasperk, R. (1988). Algae-derived (phycogene) hydroxylapatite: a comparative histological study. Int. J. Oral Maxillofac. Surg. 17, 319-324. doi: 10.1016/s0901-5027(88)80012-2

Kelaher, B. P. (2002). Influence of physical characteristics of coralline turf on associated macrofaunal assemblages. Mar. Ecol. Prog. Ser. 232, 141-148. doi: 10.3354/meps232141

Kelaher, B. P., and Castilla, J. C. (2005). Habitat characteristics influence macrofaunal communities in coralline turf more than mesoscale coastal upwelling on the coast of Northern Chile. Estuar. Coast. Shelf Sci. 63, 155-165. doi: 10.1016/j.ecss.2004.10.017

Kelaher, B. P., Chapman, M. G., and Underwood, A. J. (2001). Spatial patterns of diverse macrofaunal assemblages in coralline turf and their associations with environmental variables. J. Mar. Biol. Assoc. U.K. 81, 917-930. doi: 10.1017/ s0025315401004842

Keser, M., and Larson, B. R. (1984). Colonization and growth of Ascophyllum nodosum (Phaeophyta) in Maine. J. Phycol. 20, 83-87. doi: 10.1111/j.0022-3646. 1984.00083.x

Kim, S. K., and Chojnacka, K. (eds) (2015). Marine Algae Extracts: Processes, Products, and Applications, Vol. 2. Hoboken, NJ: John Wiley and Sons.
Lazo, L., and Chapman, A. R. O. (1997). Effects of harvesting on Ascophyllum nodosum (L.) Le Jol. (Fucales, Phaeophyta): a demographic approach. Oceanogr. Literat. Rev. 4:385.

Littler, M. M., and Kauker, B. J. (1984). Heterotrichy and survival strategies in the red alga Corallina officinalis L. Bot. Mar. 27, 37-44.

Mac Monagail, M., Cornish, L., Morrison, L., Araújo, R., and Critchley, A. T. (2017). Sustainable harvesting of wild seaweed resources. Eur. J. Phycol. 52, 371-390. doi: 10.1080/09670262.2017.1365273

Marriner, N., Morhange, C., Boudagher-Fadel, M., Bourcier, M., and Carbonel, P. (2005). Geoarchaeology of Tyre's ancient northern harbour, Phoenicia. J. Archaeol. Sci. 32, 1302-1327. doi: 10.1016/j.jas.2005.03.019

Martone, P. T. (2010). Quantifying growth and calcium carbonate deposition of Calliarthron cheilosporioides (Corallinales, Rhodophyta) in the field using a persistent vital stain. J. Phycol. 46, 13-17. doi: 10.1111/j.1529-8817.2009.00770.x

Matty, P. J., and Johansen, H. W. (1981). A histochemical study of Corallina officinalis (Rhodophyta, Corallinaceae). Phycologia 20, 46-55. doi: 10.2216/ i0031-8884-20-1-46.1

McLaughlin, E., Kelly, J., Birkett, D., Maggs, C., and Dring, M. (2006). Assessment of the Effects of Commercial Seaweed Harvesting on Intertidal and Subtidal Ecology in Northern Ireland. Environment and Heritage Service Research and Development Series, 1-90.

Meland, M., and Rebours, C. (2012). Introduction to the management and regulation of Norwegian seaweed industry. Bioforsk Fokus 7, $275-277$.

Mesnildrey, L., Jacob, C., Frangoudes, K., Reunavot, M., and Lesueur, M. (2012). Seaweed Industry in France. Report Interreg Program NETALGAE. Rennes: Agrocampus Ouest. 34.

Millar, R. B., and Anderson, M. J. (2004). Remedies for pseudoreplication. Fish. Res. 70, 397-407. doi: 10.1016/j.fishres.2004.08.016

Moorhouse, T. P., Poole, A. E., Evans, L. C., Bradley, D. C., and Macdonald, D. W. (2014). Intensive removal of signal crayfish (Pacifastacus leniusculus) from rivers increases numbers and taxon richness of macroinvertebrate species. Ecol. Evol. 4, 494-504. doi: 10.1002/ece3.903

Morrissey, J., Kraan, S., and Guiry, M. (2001). A Guide to Commercially Important Seaweeds on the Irish Coast. Dublin: Bord Iascaigh Mhara.

Munda, I. (1977). A comparison of the north- and south-European associations of Corallina officinalis. Hydrobiologia 52, 73-87. doi: 10.1007/bf02 658084

Nelson, W. A. (2009). Calcified macroalgae-critical to coastal ecosystems and vulnerable to change: a review. Mar. Freshw. Res. 60, 787-801.

Nielsen, B. D., Ryan, E. C., and O'Connor-Robison, C. I. (2011). “A marine mineral supplement for Aquacid ${ }^{\mathrm{TM}}$," in Applied Equine Nutrition and Training, ed. A. Lindner (Wageningen: Wageningen Academic Publishers).

O’Toole, E., and Hynes, S. (2014). "An Economic Analysis of the Seaweed Industry," in Proceedings of the SEMRU Working Paper, (Galway).

Pardo, C., Pena, V., Barreiro, R., and Bárbara, I. (2015). A molecular study of Corallina sensu lato (Corallinales, Rhodophyta) in the Atlantic Iberian Peninsula. Cryptogam. Algol. 36, 31-54. doi: 10.7872/crya.v36.iss1.2015.31

Perkins, R. G., Williamson, C. J., Brodie, J., Barillé, L., Lavaud, J., Yallop, M. L., et al. (2016). Microspatial variability in community structure and photophysiology of calcified macroalgal microbiomes revealed by coupling of hyperspectral and high-resolution fluorescence imaging. Sci. Rep. 6:22343. doi: 10.1038/srep22343

Petraitis, P. S., Methratta, E. T., Rhile, E. C., Vidargas, N. A., and Dudgeon, S. R. (2009). Experimental confirmation of multiple community states in a marine ecosystem. Oecologia 161, 139-148. doi: 10.1007/s00442-009-1350-9

Pringle, J. D., and Sharp, G. J. (1980). Multispecies resource management of economically important marine plant communities of eastern Canada. Helgol. Meersunters 33, 711-720. doi: 10.1007/bf02414791

R Core Team (2015). R: A Language and Environment for Statistical Computing. Vienna: R Foundation for Statistical Computing.

Rebours, C., Marinho-Soriano, E., Zertuche-González, J. A., Hayashi, L., Vásquez, J. A., Kradolfer, P., et al. (2014). Seaweeds: an opportunity for wealth and sustainable livelihood for coastal communities. J. Appl. Phycol. 26, 1939-1951. doi: 10.1007/s10811-014-0304-8

Reed, M. S. (1907). The Economic Seaweeds of Hawaii and their Food Value. Washington, DC: US Government Printing Office.

Rocha, D., Seca, A., and Pinto, D. (2018). Seaweed secondary metabolites in vitro and in vivo anticancer activity. Mar. Drugs 16, 410. doi: 10.3390/md16110410 
Ryan, S., O'Gorman, D. M., and Nolan, Y. M. (2011). Evidence that the marine-derived multi-mineral Aquamin has anti-inflammatory effects on cortical glial-enriched cultures. Phytother. Res. 25, 765-767. doi: 10.1002/ ptr.3309

Sánchez-Moyano, J. E., Estacio, F. J., García-Adiego, E. M., and García-Gómez, J. C. (2000). The molluscan epifauna of the alga Halopteris scoparia in Southern Spain as a bioindicator of coastal environmental conditions. J. Molluscan Stud. 66, 431-448. doi: 10.1093/mollus/66.4.431

Saunders, G. W. (2005). Applying DNA barcoding to red macroalgae: a preliminary appraisal holds promise for future applications. Philos. Trans. R. Soc. B 360, 1879-2188.

Smale, D. A., Burrows, M. T., Moore, P., O’Connor, N., and Hawkins, S. J. (2013). Threats and knowledge gaps for ecosystem services provided by kelp forests: a northeast Atlantic perspective. Ecol. Evol. 3, 4016-4038. doi: 10.1002/ece3.774

Stagnol, D., Renaud, M., and Davoult, D. (2015). Unravelling the impact of harvesting pressure on canopy-forming macroalgae. Mar. Freshw. Res. 67, $153-161$.

Stewart, J. G. (1982). Anchor species and epiphytes in intertidal algal turf. Pac. Sci. 36, 45-59.

Strain, E. M. A., Allcock, A. L., Goodwin, C. E., Maggs, C. A., Picton, B. E., and Roberts, D. (2012). The long-term impacts of fisheries on epifaunal assemblage function and structure, in a special area of conservation. J. Sea Res. 67, 58-68. doi: 10.1016/j.seares.2011.10.001

Thomas, N., and Kim, S. K. (2013). Beneficial effects of marine algal compounds in cosmeceuticals. Mar. Drugs 11, 146-164. doi: 10.3390/md11010146

Turhani, D., Cvikl, B., Watzinger, E., Weissenbock, M., Yerit, K., Thurnher, D., et al. (2005). In vitro growth and differentiation of osteoblast-like cells on hydroxyapatite ceramic granule calcified from red algae. J. Oral Maxillofac. Surg. 63, 793-799. doi: 10.1016/j.joms.2005.02.015

Vasquez, J. A. (1995). Ecological effects of brown seaweed harvesting. Bot. Mar. 38, 251-258.

Walker, G., Buchanan, F., Walsh, P., Dring, M., and Maggs, C. (2007). International patent application no. "PCT/GB2007/001844.

Walker, R. H., Brodie, J., Russell, S., Irvine, L. M., and Orfanidis, S. (2009). Biodiversity of coralline algae in the northeastern Atlantic including Corallina caespitosa sp. nov. (Corallinoideae, Rhodophyta). J. Phycol. 45, 287-297. doi: 10.1111/j.1529-8817.2008.00637.x

Walsh, P. J., Buchanan, F. J., Dring, M., Maggs, C., Bell, S., and Walker, G. M. (2008). Low-pressure synthesis and characterisation of hydroxyapatite derived from mineralised red algae. Chem. Eng. J. 137, 173-179. doi: 10.1016/j.cej.2007. 10.016

Walsh, P. J., Walker, G. M., Maggs, C. A., and Buchanan, F. J. (2010). Thermal preparation of highly porous calcium phosphate bone filler. J. Mater. Sci. 21, 2281-2286. doi: 10.1007/s10856-010-4056-y

Walsh, P. J., Walker, G. M., Maggs, C. A., and Buchanan, F. J. (2011). A study of the relationship between process conditions and mechanical strength of mineralised red algae in the preparation of a marine-derived bone void filler. Proc. Instit. Mech. Eng. Part H 225, 563-574. doi: 10.1177/0954411910 396306

Wang, Y., Naumann, U., Wright, S., and Warton, D. (2015). mvabund: Statistical Methods for Analysing Multivariate Abundance Data. R package version 3.10.4. Available at: http://CRAN.R-project.org/package=mvabund

Warton, D. I., Foster, S. D., De'ath, G., Stoklosa, J., and Dunstan, P. K. (2015). Model-based thinking for community ecology. Plant Ecol. 216, 669-682. doi: 10.1007/s11258-014-0366-3

Williamson, C. J., Walker, R. H., Robba, L., Yesson, C., Russell, S., Irvine, L. M., et al. (2015). Toward resolution of species diversity and distribution in the calcified red algal genera Corallina and Ellisolandia (Corallinales, Rhodophyta). Phycologia 54, 2-11. doi: 10.2216/14-024.1

Wilson, S., Blake, C., Berges, J. A., and Maggs, C. A. (2004). Environmental tolerances of free-living coralline algae (maerl): implications for European conservation. Biol. Conserv. 120, 283-293.

WoRMS Editorial Board (2015). World Register of Marine Species. Available at: http://www.marinespecies.org at VLIZ. (accessed November 15, 2016)

Yang, L.-E., Lu, Q.-Q., and Brodie, J. (2017). A review of the bladed Bangiales (Rhodophyta) in China: history, culture and taxonomy. Eur. J. Phycol. 52, 251-263. doi: 10.1080/09670262.2017.1309689

Conflict of Interest Statement: The authors declare that the research was conducted in the absence of any commercial or financial relationships that could be construed as a potential conflict of interest.

Copyright (C) 2019 Magill, Maggs, Johnson and O'Connor. This is an open-access article distributed under the terms of the Creative Commons Attribution License (CC BY). The use, distribution or reproduction in other forums is permitted, provided the original author(s) and the copyright owner(s) are credited and that the original publication in this journal is cited, in accordance with accepted academic practice. No use, distribution or reproduction is permitted which does not comply with these terms. 